\title{
Spontaneous transvaginal small bowel evisceration following hysterectomy: a case report
}

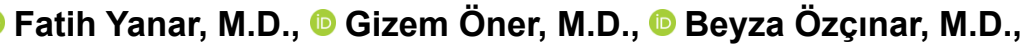 \\ (ㄷ) Ali Fuat Kaan Gök, M.D., (1) Cemalettin Ertekin, M.D.
}

Department of General Surgery, İstanbul University Faculty of Medicine, İstanbul-Turkey

\begin{abstract}
Transvaginal small bowel evisceration is a rare, life-threatening condition, requiring urgent surgical intervention. In our case, ischemia developed in the intestinal segment with evisceration, with a laceration in the small intestine of the mesentery, and finally, a small bowel resection was required. An 89-year-old woman was brought to the hospital with a sudden onset of abdominal pain, which lasted for 4 hours. Upon the examination, it was found that approximately $50 \mathrm{~cm}$ of the small intestine was eviscerated from the vagina, with its mesentery. The intestines were edematous, and also there were signs of ischemia on the mesentery. The patient was urgently transferred to surgery. Functional end-to-end anastomosis was performed, following a $70 \mathrm{~cm}$ small bowel resection. The vaginal defect was repaired transvaginally. Transvaginal small bowel evisceration is rarely described in the literature. It is most commonly seen in postmenopausal, elderly women who underwent vaginal surgery before and who have enterocele. The treatment is an emergent surgical approach. Surgical treatment should be based on individual patient. Various surgical techniques have been described for the repair of transvaginal small bowel evisceration, such as vaginal, abdominal, laparoscopic, and combined approaches. Transvaginal small bowel evisceration should be considered in the differential diagnosis of patients with a sudden onset abdominal pain. Patients with an increased risk for transvaginal small bowel evisceration are postmenopausal women and patients who underwent vaginal surgery before. After the accurate diagnosis, patients should be operated as soon as possible, and necessary surgery should be done.
\end{abstract}

Keywords: Post-hysterectomy; small bowel evisceration; vaginal surgery.

\section{INTRODUCTION}

Transvaginal small bowel evisceration is rare, but emergency surgery is required because of its potential morbidity and mortality. The risk factors include previous vaginal surgery, enterocele, and advanced age. ${ }^{[1,2]}$ Although it usually presents with a less dramatic clinical condition, surgery is necessary to prevent complications, such as bowel ischemia, ileus, and peritonitis. In our case, the findings of ischemia developed in the intestinal segment with evisceration, so we wanted to describe the risk factors, clinical findings, and treatment modalities of this condition, which is rare in general surgery practice.

\section{CASE REPORT}

An 89-years-old female patient was admitted to the emergency surgery outpatient clinic with a sudden onset, increasing abdominal pain for 4 hours, and vaginal protrusion of bowels (Fig. Ia). Her detailed history showed that she did not have any trauma history or any complaints such as constipation or cough that would increase the intra-abdominal pressure.

The patient had hypertension, so she was taking antihypertensive drugs regularly. Transabdominal hysterectomy was performed in a private center with a diagnosis of uterine prolapse 3 years before, and no postoperative complications developed.

Cite this article as: Yanar F, Öner G, Özçınar B, Gök AFK, Ertekin C. Spontaneous transvaginal small bowel evisceration following hysterectomy: a case report. Ulus Travma Acil Cerrahi Derg 2019;25:424-426.

Address for correspondence: Gizem Öner, M.D.

İstanbul Üniversitesi Tıp Fakültesi, Cerrahi Binası, I. Kat, Genel Cerrahi Sekreterlik, 3409। İstanbul, Turkey

Tel: +90 212 - 2555542 E-mail: onergizem@hotmail.com 
The patient was taken to the emergency surgery resuscitation room. She was stable, and her blood pressure was measured as $110 / 70 \mathrm{mmHg}$. The pulse rate was $85 / \mathrm{min}$. Extensive tenderness was detected on abdominal examination. On the pelvic examination, it was observed that, approximately 50 $\mathrm{cm}$ of the small intestine accompanied by mesentery was discharged from the vagina, and the circulation of the intestines was deteriorated, while the intestine was hyperemic and edematous. It was detected in blood measurements as $\mathrm{Hb} / \mathrm{Htc}$ $11.6 \mathrm{~g} / \mathrm{dL} / 36 \%$; leukocytes, $9000 / \mathrm{mm}^{3}$; and lactate, 2.6. The intestines were covered with a hot and sterile saline-soaked compress, and the patient was taken to the operating room. The patient was also pre-op consulted by a gynecologist. Wide-spectrum antibiotic therapy was initiated with an appropriate fluid support before the operation.

The patient underwent laparotomy with a median incision. In the exploration, it was seen that the loops of the small intestine were herniated from the vaginal stump. The intestinal loops were reduced to the abdomen. About $70 \mathrm{~cm}$ of the ileal loop starting $20 \mathrm{~cm}$ from the proximal end of the ileocecal valve was found to be edematous, hyperemic, and locally ischemic, and also hematomas and locally lacerated areas in the mesentery of intestinal loop were detected. The abdomen was clean, and no intestinal content or pus was detected in the abdomen. The resection of the intestinal loops was made because the vascularization had not improved despite of warming with a hot compress for 20 minutes. A $70 \mathrm{~cm}$ small intestine resection was performed $20 \mathrm{~cm}$ from the proximal end of the ileocecal valve. Proximal and distal ileal vascularization was normal. Side-by-side small intestine anastomosis was performed with staples using a $55 \mathrm{~mm}$ and a $75 \mathrm{~mm}$ linear stapler. Per-op consultation was made with the gynecologist. The vaginal stump was closed with the continuous suture and no. I vicryl (Fig. Ib). A $10 \mathrm{~mm}$ aspirate drain was placed to the Douglas pouch. The patient was taken to the service room after the operation. On the postoperative $3^{\text {rd }}$ day, she started to drink liquids and was discharged on the $6^{\text {th }}$ postoperative day. No complications were observed in the first-week and the first-month follow-up.

\section{DISCUSSION}

The definition of spontaneous vaginal small bowel evisceration was first made by Hyernaux in $1864 .^{[1]}$ It is a rare, life-threatening condition that requires an urgent surgical intervention, and less than 100 cases have been described in the literature. [2,3] Unfortunately, there is not enough information about the recurrence rate of transvaginal small bowel evisceration in the literature. In a review of the study by Kowalski et al., ${ }^{[3]}$ $68 \%$ of the patients who developed vaginal evisceration were postmenopausal. Of these patients, $73 \%$ had previous vaginal surgery, and $63 \%$ had enterocele. A more frequent occurrence in postmenopausal women has been associated with decreased vaginal wall attenuation, atrophy, and decreased vascularity due to reduced estrogen. ${ }^{[4,5]}$ Risk factors in premenopausal women are trauma caused by coitus, rape, and foreign bodies. The risk factors in postmenopausal women are an advanced age, previous vaginal surgical interventions, enterocele repair, and sudden increases in intra-abdominal pressure (cough, constipation). ${ }^{[6,7]}$ Other previously reported risk factors include radiotherapy, abdominal or vaginal hysterectomy, perineal proctectomy, and it is rarely spontaneous..$^{[5,7]}$ Vaginal rupture in postmenopausal women is mostly from posterior fornix..$^{[3,4]}$

Transvaginal small bowel evisceration is a surgical emergency and is associated with a $6 \%-10 \%$ mortality rate due to septicemia and thromboembolism. Complications related to vaginal small bowel herniation are bowel ischemia, intraabdominal sepsis, ileus, and deep vein thrombosis. ${ }^{[5,6,8]}$ It is possible to reduce morbidity and mortality with an early diagnosis and appropriate emergency surgical intervention.

Various surgical techniques have been described for the repair of transvaginal small bowel evisceration such as vaginal, abdominal, laparoscopic, and combined approaches. Surgical treatment should be decided based on the individual patient. If there is no evidence of ischemia in the eviscerated intestinal segment, and if it can be reduced to the peritoneal cavity without complications, it is possible to repair the vaginal
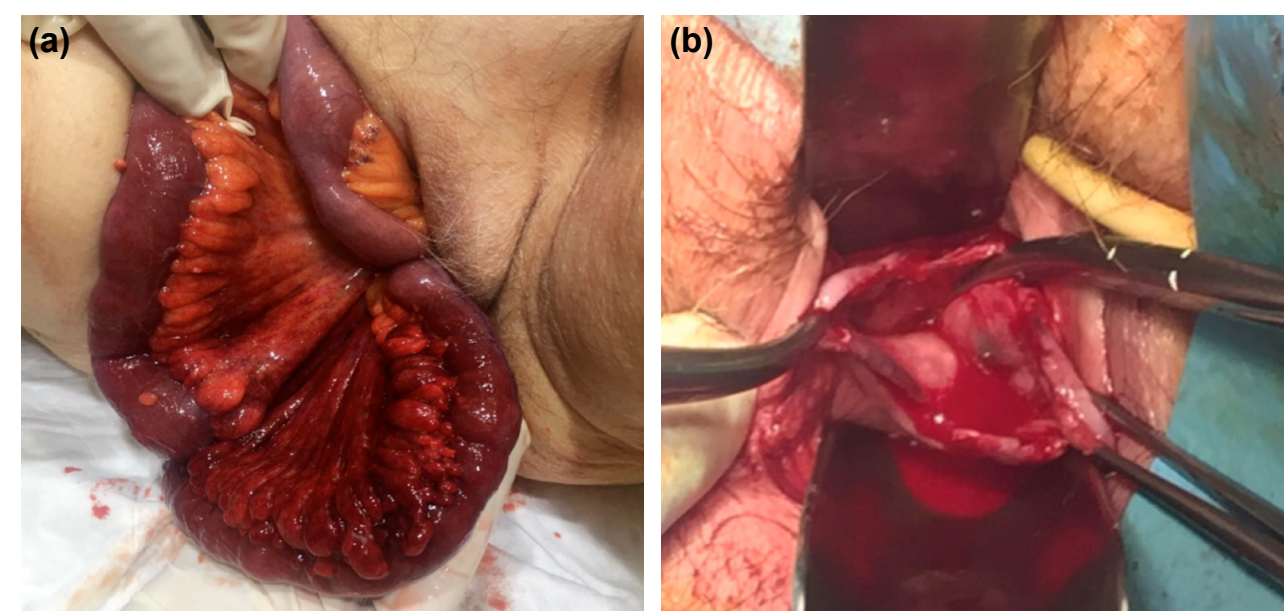

Figure 1. (a) On pelvic examination, small intestine with hyperemia and edema was discharge from vagina. (b) Vaginal stump was repaired transvaginally. 
defect with the vaginal approach. ${ }^{[2,6,8-10]}$ Matthews et al. ${ }^{[1]}$ concluded that transvaginal approach should be used only if the patient is medically stable and has no clinical evidence of peritonitis or bowel ischemia. If the intestinal segment cannot be reduced, and if strangulation findings are present, laparotomy should be performed, intestinal segments should be reduced into the abdomen, and intestinal segments should be evaluated carefully for ischemia. In our case, laparotomy was chosen because of the presence of ischemic findings in the intestinal segment, and there was laceration on mesentery. In addition, we chose laparotomy considering that the size of the vaginal defect may have caused air leakage.

On the exploration, an area of ischemia was detected in the intestinal segment, a resection decision was made, and approximately $70 \mathrm{~cm}$ of the small intestine was resected. The anastomosis was deemed appropriate because of the good blood supply of the intestinal ends after the resection. Subsequently, the vaginal defect was repaired by the obstetrics and gynecology team. The vaginal stump was closed with continuous sutures and no. I vicryl, but also, there are different ways of closing the vaginal stump, such as continuous sutures or separated sutures. In addition, some surgeons propose to reinforce the vaginal stump with the graft or omental flap. ${ }^{[12,13]}$ In this case, they were not used due to the patient's age.

Transvaginal small bowel evisceration is a rare condition that requires emergency surgery because it is life-threatening. Early diagnosis and an appropriate surgical intervention are required. As in our case, early surgical intervention with small bowel resection is appropriate for patients with ischemic findings in the intestine, and an early surgical intervention will contribute to the reduction in the mortality and morbidity, prevention of the short bowel syndrome development, and the protection of the small bowel.

\section{Conflict of interest: None declared.}

\section{REFERENCES}

1. Hyernaux M. Rupture traumatique du vagin; issue des intestines a l'extieur, application du grand forceps au Detroit superieur; gurison. Bull Mem Acad Med Belg 1864;2:957.

2. Ramirez PT, Klemer DP. Vaginal evisceration after hysterectomy: a literature review. Obstet Gynecol Surv 2002;57:462-7. [CrossRef]

3. Kowalski LD, Seski JC, Timmins PF, Kanbour AI, Kunschner AJ, Kanbour-Shakir A. Vaginal evisceration: presentation and management in postmenopausal women. J Am Coll Surg 1996;183:225-9.

4. O'Brien LM, Bellin LS, Isenberg GA, Goldstein SD. Spontaneous transvaginal small-bowel evisceration after perineal proctectomy: report of a case and review of the literature. Dis Colon Rectum 2002;45:698-9.

5. Dharmalingam M, Greenhalf JO, Smith KM. Vaginal evisceration following total abdominal hysterectomy. J Obstet Gynaecol 2004;24:194-5.

6. Partsinevelos GA, Rodolakis A, Athanasiou S, Antsaklis A. Vaginal evisceration after hysterectomy: a rare condition a gynecologist should be familiar with. Arch Gynecol Obstet 2009;279:267-70. [CrossRef]

7. Thomson AJ, Elbiss HE. Re: Vaginal evisceration following total laparoscopic hysterectomy: case report and review of the literature. Aust N Z J Obstet Gynaecol 2008;48:447-8. [CrossRef]

8. Ho PW, Lee CW. Transvaginal small bowel evisceration and strangulation. ANZ J Surg 2008;78:726-7. [CrossRef]

9. Rajesh S, Kalu E, Bong J, Wales N. Evisceration 5 years post abdominal hysterectomy. J Obstet Gynaecol Res 2008;34:425-7. [CrossRef]

10. Somkuti SG, Vieta PA, Daugherty JF, Hartley LW, Blackmon EB Jr. Transvaginal evisceration after hysterectomy in premenopausal women: a presentation of three cases. Am J Obstet Gynecol 1994;171:567-8.

11. Matthews CA, Kenton K. Treatment of vaginal cuff evisceration. Obstet Gynecol 2014;124:705-8. [CrossRef]

12. Narducci F, Sonoda Y, Lambaudie E, Leblanc E, Querleu D. Vaginal evisceration after hysterectomy: the repair by a laparoscopic and vaginal approach with a omental flap. Gynecol Oncol 2003;89:549-51. [CrossRef]

13. Ben Safta Y, Ghalleb M, Baccari A, Hamdi El Kebir G, Daldoul S, Sayari S, et al. Vaginal cuff dehiscence and evisceration 11 years after a radical hysterectomy: A case report. Int J Surg Case Rep 2017;41:234-7. [CrossRef]

\section{OLGU SUNUMU - ÖZET}

\section{Histerektomi sonrası geç dönem transvajinal ince bağırsak evisserasyonu: Olgu sunumu \\ Dr. Fatih Yanar, Dr. Gizem Öner, Dr. Beyza Özçınar, Dr. Ali Fuat Kaan Gök, Dr. Cemalettin Ertekin}

İstanbul Üniversitesi İstanbul Tıp Fakültesi, Genel Cerrahi Anabilim Dalı, İstanbul

Transvajinal ince bağırsak evisserasyonu nadir görülmekle birlikte, tanı konulduğu anda acil cerrahi girişim gerektiren bir klinik tablodur. Olgumuzda da evissere olan bağırsak segmentinde iskemi bulguları gelişmiş, ince bağırsak mezosunda yırtık oluşmuş ve ince bağırsak rezeksiyonu yapılması gerekmiştir. Seksen dokuz yaşında kadın hasta dört saattir olan ani başlayan karın ağrısı, bağırsakların vajinadan çıkma şikayeti ile getirildi. Hastanın yapılan muayenesinde yaklaşık 50 cm'lik ince bağırsak ansının mezosu ile birlikte vajenden evissere olduğu görüldü. Bağırsak ansları ödemli olup, yer yer iskemi bulguları ve mezoda yırtılma mevcuttu. Hasta acil olarak ameliyata alındı. Yetmiş cm'lik ince bağırsak rezeksiyonunu takiben fonksiyonel uc-uca anastomoz yapıldı. Vajen defekti transvajinal olarak çift kat üzerinden tamir edildi. Transvajinal ince bağırsak evisserasyonu literatürde az rastlanan bir durumdur. En sık postmenapozal, yaşlı, daha önceden geçirilmiş vajinal ameliyatı olan, enteroseli olan kadınlarda görülmektedir. Tedavisi acil cerrahi girişimdir. Yapılacak cerrahi hastanın bulgularına göre transvajinal olarak vajen güdüğünün tamir edilmesinden, laparotomi yapılmasına hatta bağırsak rezeksiyonu yapılmasına kadar değişiklik gösterebilir. Postmenapozal, daha önceden geçirilmiş vajinal ameliyatı olan hastalar gibi risk taşıyan hastalar ani başlayan karın ağrısı ile başvurduklarında transvajinal ince bağırsak evisserasyonu da ayırıcı tanıda düşünülmelidir. Tanısı konulduktan sonra da hastalar en kısa sürede ameliyata alınıp gerekli cerrahi girişim yapılmalıdır.

Anahtar sözcükler: İnce bağırsak evisserasyonu; post-histerektomi; vajinal cerrahi.

Ulus Travma Acil Cerrahi Derg 2019;25(4):424-426 doi: 10.14744/tjtes.2019.57318 